\title{
Brain Natriuretic Peptide to Predict Successful Liberation from Mechanical Ventilation in Critically III Patients: a Systematic Review and Meta-Analysis
}

Jean Deschamps ( $\nabla$ jean3@ualberta.ca )

Faculty of Medicine and Dentistry, University of Alberta https://orcid.org/0000-0002-4872-3334

\section{Sarah K. Andersen}

University of Alberta

Jordan Webber

University of Alberta

Robin Featherstone

University of Alberta

Meghan Sebastianski

University of Alberta

Ben Vandermeer

University of Alberta

Janek Senaratne

University of Alberta

Sean M. Bagshaw

University of Alberta

\section{Research}

Keywords: Natriuretic Peptide, Brain, Respiration, Artificial, Ventilator Weaning, Intensive Care, Critical Care

Posted Date: January 23rd, 2020

DOl: https://doi.org/10.21203/rs.2.19088/v2

License: @ (i) This work is licensed under a Creative Commons Attribution 4.0 International License. Read Full License

Version of Record: A version of this preprint was published at Critical Care on May 11th, 2020. See the published version at https://doi.org/10.1186/s13054-020-2823-9. 


\section{Abstract}

Background: Predicting successful liberation from mechanical ventilation (MV) in critically ill patients is challenging. Brain natriuretic peptide (BNP) has been proposed to help guide decision-making for readiness to liberate from MV following a spontaneous breathing trial (SBT).

Methods : We performed a systematic review and meta-analysis of randomized and prospective observational studies that measured BNP levels at the time of SBT in patients receiving MV. The primary endpoint was successful liberation from MV (absence of re-intubation or non-invasive ventilation at 48h). Statistical analyses included bi-variate and Moses-Littenberg models, and DerSimonian-Laird pooling of areas under ROC curve (AUROC).

Results: A total of 731 articles were screened. Eighteen adult and 2 pediatric studies were fulfilled pre-specified eligibility. The measure of the relative variation of BNP during SBT (DBNP\%) after exclusion of SBT failure by clinical criteria in adults yielded a sensitivity and specificity of 0.889 [0.831-0.929] and 0.828 [0.730-0.896] for successful liberation from MV respectively, with a pooled AUROC of 0.92 [0.88-0.97]. The pooled AUROC for any method of analysis for absolute variation of BNP (DBNP), pre-SBT BNP and post-SBT BNP were 0.89 [0.83-0.95], 0.77 [0.63-0.91], and 0.85 [0.80-0.90], respectively.

Conclusion: The relative change in BNP during a SBT has potential value as an incremental tool after successful SBT to predict successful liberation from MV in adults. There is insufficient data to support the use of BNP in children or as an alternate test to clinical indices of SBT or the use of DBNP, BNP-pre and BNP-post as an alternate or incremental test.

Trial registration number: PROSPERO CRD42018087474 (2018-02-06)

\section{Introduction}

Predicting successful liberation from mechanical ventilation (MV) among critically ill patients can be challenging, and there are no standardized methods for assessing readiness for extubation(1). The American College of Chest Physicians/American Thoracic Society (ACCP/ATS) clinical practice guideline (CPG) on liberation from MV suggests a spontaneous breathing trial (SBT) with inspiratory pressure support as the preferred technique; however, this recommendation is based on limited evidence $(1,2)$. Morever, the majority of parameters used to determine whether SBT has been successful are physiologic variables that inconsistently predict successful liberation from MV(3-5). Brain natriuretic peptide (BNP) has been proposed as a novel biomarker to help predict successful liberation from MV. To date, CPGs have not integrated evidence from studies evaluating BNP to predict successful liberation from MV.

BNP is a sensitive marker of myocardial stretch, and its relative change in patients during a SBT has been proposed to provide incremental value to predict successful liberation from $M V(3,5,6)$. BNP is a natriuretic peptide released from cardiomyocytes, measured using one of the two widely available assays (NT-proBNP and BNP). The half-life of BNP is estimated to be 20 minutes, while the half-life of NT-proBNP is estimated at 120 minutes(6). Subclinical congestion and overt pulmonary edema due to changes in left ventricular afterload may be common during a SBT. These physiologic changes may be readily detected by measuring changes in BNP(7-11). Existing studies have attempted to incorporate BNP at various steps of liberation from MV. The focus of this study will be the use of BNP during a SBT.

Accurate and reliable prediction of extubation failure is clinically important, as extubation failure is known to have greater risk of adverse outcomes including reintubation, nosocomial pneumonia, mortality, and prolonged length of intensive care unit (ICU) stay $(2,12-14)$ Development and validation of rigorous methods incorporating BNP (both BNP and NT-proBNP will be hereto referred to as BNP for the purpose of this manuscript) may augment clinician decision support, rates of successful liberation from MV and improve patient outcomes. The objective of this systematic review 
was to rigorously evaluate the value of BNP measurement with a SBT as a biomarker to predict liberation from MV among critically ill ICU patients. We hypothesized that BNP would add incremental predictive value for successful liberation from MV compared with standard clinical and biochemical parameters assessed during SBT.

\section{Methods}

The systematic review protocol has been registered with the PROSPERO International Prospective Register of Systematic Reviews (Registration number CRD42018087474 on 2018-02-06), and has been published (2019-02-12)(15). Data were sourced from available published and unpublished studies. As such, no patient-specific primary data were collected and research ethics approval was not required.

Search Strategy and Study Identification

Search methods

The search strategy was developed and executed by a research librarian (RF) and was peer-reviewed by a second research librarian (Additional file 1) (16-20). We searched electronic databases: Ovid MEDLINE (1946-); Ovid EMBASE (1974-); Wiley Cochrane Library (inception-), including the Cochrane Database of Systematic Reviews (CDSR) and the Cochrane Central Register of Controlled Trials (CENTRAL); and Web of Science Core Collection via Clarivate Analytics (1900-). A combination of the following search themes were used: 1) brain natriuretic peptide, any subtype, and 2) weaning, extubation, or liberation from mechanical ventilation. Results were limited to human studies, published in any language from database inception. Bibliographic records were exported to an EndNote X7 (Thomson Reuters, Philadelphia, Pennsylvania) database for duplicate removal and screening. Additional sources were included in the search strategy. The cited and citing references of included studies and relevant review articles were screened. We also searched trial registry records via ClinicalTrials.gov, and meeting abstracts via the Conference Proceedings Citation Index (Clarivate Analytics). Finally, we identified relevant clinical practice guidelines by searching Choosing Wisely Canada, the National Guidelines Clearinghouse, and TRIP (Turning Research Into Practice) Database.

Study assessment

We included all relevant randomized and pseudo-randomized controlled trials (defined as controlled trials in which patients are randomized according to methods other than concealed random allocation) that measured BNP levels at the time of SBT in patients receiving MV. We also included prospective observational studies that described BNP levels during SBT and assessed for any association with successful extubation rates. We excluded retrospective studies since the timing of BNP measurement relative to SBT was of critical importance for the purpose of this study and may have been prone to bias. We included studies reported as full text, published as an abstract only, and any relevant unpublished data obtained from the authors. There was no language restriction.

Studies were included if they involved patients receiving invasive MV in whom SBT was performed. There were no age restrictions. We included studies with BNP assay of any type (BNP, NT-proBNP, etc.) if performed within 120 minutes of the SBT. There were no restrictions on SBT type. We excluded studies with insufficient data for the outcomes measured when we were unable to obtain the necessary original data from the primary authors.

Eligible articles were identified through two phases. In the first phase, two authors (JD and JW) independently reviewed the titles and abstracts of all retrieved bibliographic records using EndNote X7 (Thomson Reuters, Philadelphia, Pennsylvania) for potential inclusion. In the second phase, full texts of the selected articles were retrieved and two authors (JD and JW) independently reviewed and selected studies that met the inclusion criteria.

Data extraction

Page 3/19 
For full-text studies selected for inclusion, relevant information was abstracted using piloted and standardized electronic data forms by two authors independently (JD and SA) (Additional file 2). Abstracted data was then compared between the two authors. Disagreements at every step were resolved through discussion and a third author (SMB) was available for arbitration.

Data analysis and synthesis

The primary endpoint was successful liberation from MV. Successful liberation was defined in accordance with existing literature as the absence of re-intubation or application of new non-invasive ventilation in the 48 hours following initial extubation(1). We further analysed additional data after 48 hours as available. Secondary endpoints initially described in our protocol could not be analysed due to insufficient available data.

We examined and compared the characteristics of patients that had failed extubation compared to those that had successful extubation. For binary variables (e.g., sex) we computed odds ratio, while for continuous variables (e.g., age) we computed mean differences. When results from multiple studies were available, we pooled data using a DerSimonian-Laird random effects model. All results were presented with $95 \%$ confidence intervals. Heterogeneity was examined using the I-squared statistic.

Diagnostic accuracy of BNP was measured using sensitivity and specificity. In this instance, a true positive was represented by the combination of a low absolute or low variation of BNP in a patient that had successful liberation from MV. A true negative was represented by the combination of a high absolute or high variation of BNP in a patient that had unsuccessful liberation from MV. Where possible, results across studies were simultaneously pooled using a bi-variate model to create both a joint estimate of sensitivity and specificity (with 95\% confidence regions) as well as hierarchical summary ROC curve (HSROC). For subgroup analyses, we were unable to use the bi-variate model due to insufficient studies. In these cases the Moses-Littenberg model was used to estimate a summary ROC curve. When considered sufficiently clinically homogeneous, areas under the ROC curve (AUROC) were pooled when possible using a DerSimonian-Laird random effects model.

Quality assessment

Quality of each study (JD and SA) was assessed using the QUADAS-2 questionnaire for systematic reviews(22). Ten parameters across four domains (Patient selection, Index test, Reference test and Flow/timing) were analysed independently by two authors (JD and SA) and disagreements resolved through discussion. This was performed in duplicate by two independent reviewers (JD and SA). We applied the strict QUADAS-2 method of assigning low risk or at risk status for each domain. We did not perform a GRADE assessment as described in the protocol, as this was deemed not applicable to this type of research.

\section{Results}

A total of 731 articles were screened, 117 were identified for full-text review, and 20 met the prespecified eligibility criteria and were included (Figure 1, Additional file 3). Of these, 18 studies were of adult patients and 2 studies were of children (Table 1 and 2).

Adult studies

Of the 18 adult studies, there were 28 individual analyses of BNP relative to SBT. The methods of BNP measurements included: pre-SBT BNP measures (BNP-pre), post-SBT BNP measures (BNP-post), absolute BNP change during SBT (DBNP), and the relative BNP change during SBT (DBNP\% = [post-SBT BNP - pre-SBT BNP]/pre-SBT BNP). Four studies described more than one measure of BNP. Some studies did not provide a ROC analysis and relied on odds ratio (OR). A 
subset of studies assessed BNP as an alternative tool to reclassify all patients by including SBT failure in the liberation failure group for analysis (group 1; Figure 2). The other subset assessed BNP as an incremental tool in addition to SBT testing and excluded SBT failure from the analysis (group 2; Figure 2). This was unclear in one study(21). All studies relied on clinical indices of SBT to determine readiness of extubation, and no decision to extubate was done based on BNP measures. All studies excluded preventative non-invasive ventilation from the cohort of patients being analysed.

Patient baseline characteristics, primary diagnoses, acuity scores and ventilatory parameters were reported by status of liberation from MV (Additional file 4). These baseline data points were not classified according to BNP assessment results combined. All studies except one(22) evaluated the first liberation attempt $(n=17)$. All studies observed patients for extubation failure at $48 \mathrm{~h}(\mathrm{n}=18)$, with one study extending observation to 7 days(22). The quality of included studies focused on adults suggested a risk of bias for all but one low-risk study (Table 3). The main reasons for risk of bias were patient selection and lack of blinding of the index test and reference test.

Pediatrics studies

Of the two studies focused on children, one study addressed preterm infants with respiratory distress syndrome, and the other addressed congenital heart surgery patients(Table 2). Pooled analysis could not be performed due to the lack of available data. As such, these studies were excluded from the pooled analysis. Both studies were at risk of bias (Table 4).

\section{Meta-analysis}

Only 13 of the 20 studies included had sufficient data for pooled meta-analysis. We performed a single bi-variate estimate of sensitivity and specifity combining studies that reported absolute and relative changes of BNP (DBNP or DBNP\%) in studies that either included or specifically excluded patients with SBT failure from analysis $(n=5)$. The sensitivity and specificity were $0.889(0.831-0.929)$ and $0.828(0.730-0.896)$, respectively (Figure 3$)$. This was further stratified in Moses-Littenberg summary ROC curves for either measure of BNP (DBNP or DBNP\%) and for DBNP\% only in studies that excluded patients with SBT failure (Additional File 5).

AUROC were pooled separately for: DBNP $\left(n=3,0.89[0.83-0.95], I^{2}=67 \%\right)$ and DBNP\% $\left(n=5,0.92[0.87-0.96], I^{2}=28 \%\right)$ regardless of inclusion or exclusion of patients failing a SBT (Figure 4); DBNP\% for studies that excluded patients failing a SBT $\left(n=3,0.92\right.$ [0.88-0.97], $\left.I^{2}=0 \%\right)$ (Figure 5); and BNP-pre $\left(n=4,0.77\right.$ [0.63-0.91], $\left.I^{2}=87 \%\right)$ and BNP-post $(n=4,0.85[0.80$ $0.90], I^{2}=16 \%$ ) regardless of inclusion or exclusion of patients failing a SBT (Figure 6).

No meta-analysis of the specific thresholds of BNP measures could be performed due to insufficient data. A net reclassification index could not be calculated given the limited data assessing BNP measures in SBT failure groups. Only the pediatric study by Zhang et al(23) calculated a NRI of 0.224 for the addition of NT-ProBNP to SBT, suggesting an improvement in reclassification.

\section{Discussion}

Key findings

This meta-analysis supports the validity of the relative change of BNP (DBNP\%) during a SBT to add incremental value and inform the likelihood of successful liberation from MV in adults. This meta-analysis also demonstrated high accuracy using a pooled AUROC of DBNP\% for studies that excluded patients who failed a SBT. Combining methods of absolute and relative change in BNP measures, irrespective of inclusion or exclusion of patients who failed their SBT showed high sensitivity and specificity for predicting successful liberation. The data from pediatric studies and studies 
describing other BNP measures, such as DBNP, BNP-pre SBT and BNP-post SBT, were insufficient to suggest incremental value and for clinical decision support about likelihood of liberation success.

There findings are noteworthy given the limited predictive ability of SBT alone, which is generally regarded as the best available assessment. In studies, SBT misclassified patients in 10-20\% of patients who subsequently failred to successfully liberation from $M V(14,24)$. While reintubation was described as occurring without immediate difficulty, these patients had greater risk of morbidity and mortality following a failed attempt at liberation from MV(1). Better prediction by use of alternative tests that add incremental value, such as BNP, may lead to greater confidence in clinical decision-making to extubate, reduced reintubation, and improved outcomes. This possibility has been recognized as early as 2008 in two methods of analysis: as an incremental "value-added" test during SBT(3), and as a "stand-alone" alternative test(25). These two approaches were well represented in the studies included in this meta-analysis. A subset of studies (group 1, n=8) included patients failing their SBT in the analysis of the group that failed MV liberation; this in effect assessed BNP as an alternative test to conventional SBT. This method may have decreased accuracy compared to evaluation of pooled analysis where patients who failed their SBT were excluded. A second subset of studies (group 2, $\mathrm{n}=9$ ) excluded patients with a failed SBT in the analysis of the MV liberation failure group. This in effect assesses BNP as an incremental test to a successful SBT. The major benefit in this case is the potential reclassification of patients for whom liberation may have been attempted, but may have failed. This distinction is important to determine the optimal use of BNP in assessment for MV liberation. In our view, the two ways in which SBT failure is incorporated in the analysis should ideally be pooled and analysed separately. However; we expected limited data and pooled them for further analysis as planned in the protocol. Similarly, the different methods of BNP measures (DBNP, DeltaBNP\%, BNPpre and BNP-post) should not be pooled, as some address a change in BNP values, whereas others only address a single value at a specific time. The only exception in which BNP measures could be pooled would be be DBNP and DBNP\% given the possibility that baseline BNP level may not be relevant in the case of substantial change occurring during a SBT.

Most of the data that could be pooled related to absolute and relative changes in BNP during a SBT (DBNP and DBNP\%). In order to increase the breadth of our analyses, we pooled studies of either method of measures (DBNP and DBNP\%) for studies that excluded patients who failed their SBT. The Moses-Littenberg summary ROC analysis showed high accuracy (Additional File 5). However, this analysis requires the availability of true positive, true negative, false positive and false negative data to perform, limiting its applicability to certain subgroups. This summary ROC analysis was mostly driven by DBNP\% (3 out of 4 studies, 148 out of 178 patients). We were able to perform a pooled AUROC of DBNP\% for studies that excluded SBT failure from the analysis of the liberation failure (Figure 5). This AUROC analysis further supports the initial findings and provides evidence of high accuracy (0.92 [0.88-0.97], $\left.\mathrm{I}^{2} 0 \%\right)$. This represents the most robust combination of BNP measures in pooled analysis obtained from the data.

Unfortunately, the data was insufficient to perform sensitivity and specificity estimates for this specific combination of BNP measures. The closest approximation was obtained by a bi-variate analysis using pooled data of studies of either DBNP and DBNP\% measures, regardless of inclusion or exclusion of the SBT failure group. The sensitivity and specificity obtained were high [0.889 (0.831-0.929) and $0.828(0.730-0.896)$, respectively]. It is important to note that these results were mostly driven by studies where patients with SBT failure were excluded (4 out of 5 studies; 248 out of 278 patient s), and DBNP\% (4 out of 5 studies; 178 out of 278 patients). This closely approximates the prior analysis performed on DBNP\% for studies that excluded patients with SBT failure from the analysis.

There were insufficient studies to analyse DBNP, BNP-pre and BNP-post separately as an incremental test (i.e., excluding SBT failure from the liberation failure analysis) or an alternate "stand-alone" test (i.e., including SBT failure from the liberation failure analysis). Pooling studies of both methods of analysis for each BNP measure appears to support a high accuracy in these cases (Figure 4). The main limitation is the inability to determine if it is of better use as an 
incremental or alternate test. Additionally, for BNP-pre and BNP-post, the studies were not described with as much detail as those for studies on DBNP and DBNP\%. Furthermore, it is difficult to determine a superior measure or method, as only two studies directly compared various BNP measures. Both Cheng et al(26) and Martini et al(21) compared DBNP and DBNP\%, and both studies suggested DBNP\% was superior.

From a clinical standpoint, using these measures requires using a specific threshold for dichotomization between likelihood of liberation success versus failure (Table 1). This was determined through analysis of the AUC curve of best sensitivity, specificity, positive and negative predictive values and diagnostic accuracy. No pre-specified threshold was studied prospectively across any of the studies. Studies of DBNP\% suggested a threshold above $13.4-20 \%(n=4)$ optimally predicted liberation failure, if both BNP types (BNP and NT-ProBNP) were pooled. The other BNP measures had three or fewer studies for each measure or combination (Table 1). As such, this systematic review cannot recommend a specific threshold for any of the BNP measures to optimally discriminate liberation success and failure that could be adopted in clinical practice.

Our study would suggest that BNP performs best if used as a relative change BNP during a SBT among those studies that only included adult patients who successfully passed an initial SBT by other clinical criteria. There is a potential role to the use of either DBNP\% or DBNP irrespective of whether patients have successfully or unsuccessfully passed an SBT, but the data is less robust and requires further investigation.

\section{Limitations}

As described above, the heterogeneity of BNP measures and varying analytic approaches limited our ability to perform pooled analysis; acknowledging this limits the inferences that can be made. Similarly, due to limitation in the reporting across studies, we were unable to perform stratified analysis by potentially important subgroups, such as case-mixe and type of ICU admission. We opted to combine both general ICU populations and specific ICU subgroups to capture enough data to perform the AUROC analyses. The bi-variate analysis and Moses-Littenberg analyses were unaffected, as all studies included were of a mixed ICU population. We believe that this makes our results more generalizable to mixed medical/surgical ICU practice; however, we cannot provide strong inferences on the value of BNP for MV liberation in selected ICU subgroups, as each population was represented by a single study. There are several confounders to the accuracy of BNP testing. Heart disease (and specifically depressed left ventricular ejection fraction) and kidney failure can significantly alter BNP kinetics. Unfortunately, these patient characteristics were inconsistently included or excluded across studies. In the case of kidney failure, the distinction between acute and chronic renal failure was also poor. In balance, renal function was normal in most studies, and at most mildly impaired in the rest. As for heart disease, the definitions were variable. The etiology of respiratory failure has an impact on the accuracy of BNP: delirium, traumatic brain injury, inability to clear secretions or stridor, amongst others, limit the accuracy of BNP as they may not lead to a change in BNP measurements. A low number of studies that were included in this review attempted to limit this impact by excluding stridor and TBI from the analysis. Unfortunately, capturing clearance of secretions or delirium as the cause of respiratory failure is understanbly difficult and was not done in any study. Another limitation is the lack of studies that directly compared the accuracy of a successful SBT by clinical indices and by BNP measure. In this instance, a patient that has passed a SBT by clinical indices may fail by BNP measure, leading to a delay in extubating a patient that would have succeded. Unfortunately, the relative accuracies were not directly assessed in any study.

Finally, the quality of studies (as defined by QUADAS-2) uniformally ranked as at risk of bias, except for one(27). The main issue was lack of transparency regarding blinding of physicians to the BNP test. In our opinion, this is not a critical flaw, as the decision to extubate patients was most often based on clinical SBT criteria in all studies.

Implications for Clinical, Policy and Research 
Research on mechanical ventilation liberation is complex and would benefit from greater standardization. Successful liberation from mechanical ventilation appears well-defined and this is reflected in the studies collected. Liberation failure, on the other hand, has a variable definition amongst studies, mostly relating to the inclusion or exclusion of SBT failure. Regardless of its importance for applicability of alternative or incremental testing, the terms used require standardization to facilitate research.

Additional data is needed to strengthen BNP as a liberation tool. We consider that this should take the form of a comparative study of BNP as an alternative or an incremental tool to the clinical indices after an SBT. This study would ideally take the form of an assessment of DBNP and DBNP\%, and compare inclusion versus exclusion of SBT in the analysed subgroups. This would allow determination of whether BNP is superior to SBT on its own or simply incremental.

The potential benefits of improved tools to inform greater likelihood of success or failure of liberation from MV have farreaching implications. On top of reclassifying individuals after initial assessment with clinical indices, this may allow stratification of the risk of failure. Such a stratification may help better determine targets for optimization (such as further volume de-escalation), better identification of the need for post-extubation therapies (such as high-flow oxygen therapy and BiPAP), and need for prolonged ICU observation. Clinical risk scores on this basis could be developed to aid in management of these patients after extubation.

\section{Conclusion}

The relative change of BNP during a SBT (DBNP\%) would appear to have value as an incremental tool after passing a SBT for predicting successful liberation from MV. This pooled analysis, however, was limited by not enabling calculation or validation of a specific threshold, despite a number of studies reporting thresholds in the range of $13-20 \%$. As such, we submit further investigation is warranted. There was insufficient data to support DBNP\% as a stand-alone test to conventional SBT or the use of DBNP, BNP-pre and BNP-post either incrementally or as a stand-alone $s$ an alternate or incremental test. Studies comparing the best use of DBNP\% either as an alternative or incremental tool to clinical indices during SBT as well as prospective validation of a specific threshold represent the next step in research. There is a paucity data in pediatric cases that limits any conclusion.

\section{Declarations}

Ethics approval and consent to participate

Data for this review will be sourced from available published and unpublished studies, if applicable. As such, no patientspecific primary data will be collected, and formal health research ethics approval is not required.

Consent for publication

Not applicable.

Author's contribution

JD was responsible for the preparation of the manuscript. SMB, JS, JD and SA were responsible for study selection and data collection. RF developed the search strategy and conducted the search in consultation with JD, JW and SMB. MS provided support for methodology. BV provided support for statistical analysis. SMB conceived the project, and all authors provided critical revision of the protocol and final manuscript. SMB will guarantee the content of the review. 
The authors acknowledge the support of Tara Landry MLIS, for her peer-review of the Medline search strategy. The authors acknowledge the support of Sophia Yip for translation of Chinese language articles.

Funding

SMB is supported by a Canada Research Chair in Critical Care Nephrology. The project was supported by the Alberta Strategy for Patient Oriented Research (SP OR) SUPPORT Unit - Knowledge Translation Platform.

Competing interests

None declared

\section{Provenance and peer review}

Not commissioned; externally peer reviewed.

Availability of data and materials

This is an Open Access article distributed in accordance with the Creative Commons Attribution Non Commercial (CC BYNC 4.0) license, which permits other to distributed, remix, adapt, build upon this work non-commercially, and license their derivative works on different terms, provided the original work is properly cited and the use is non-commercial.

Author affiliations

${ }^{1}$ Department of Critical Care Medicine, Faculty of Medicine and Dentristry, University of Alberta, 8440112 St. NW, Critical Care Medicine 2-124E Clinical Sciences Building, Edmonton, Alberta, T6G 2B7, Canada.

${ }^{2}$ Alberta Strategy for Patient Oriented Research (SPOR) SUPPORT Unit - Knowledge Translation Platform, University of Alberta, 4-472 Edmonton Clinical Health Academy, 11405 - 87 Avenue, Edmonton, Alberta T6G 1C9, Canada.

${ }^{3}$ Alberta Research Center for Health Evidence (ARCHE), University of Alberta, 4-486D Edmonton Clinical Health Academy, 11405 - 87 Avenue, Edmonton, Alberta T6G 1C9, Canada.

${ }^{4}$ Knowledge Translation Platform, Alberta SPOR SUPPORT Unit Department of Pediatrics, University of Alberta, 362-B Heritage Medical Research Centre (HMRC)

${ }^{5}$ Division of Cardiology, Faculty of Medicine and Dentistry, University of Alberta, 8440112 St. NW, Edmonton, Alberta, Canada.

\section{Abbreviations}

$\triangle B N P \%$ - Relative variation of BNP during a SBT

MV - Mechanical Ventilation

DBNP - Absolute variation of BNP during a SBT

BNP - Brain natriuretic peptide

SBT - Spontaneous breathing trial

AUROC - Area under ROC curve 
CPG - Clinical practice guideline

ICU - Intensive care unit

HSROC - Hierarchical summary ROC curve

NIV - Non-invasive ventilation

\section{References}

1. Ouellette DR, Patel S, Girard TD, Morris PE, Schmidt GA, Truwit JD, et al. Liberation From Mechanical Ventilation in Critically III Adults: An Official American College of Chest Physicians/American Thoracic Society Clinical Practice Guideline: Inspiratory Pressure Augmentation During Spontaneous Breathing Trials, Protocols Minimizing Sedation, and Noninvasive Ventilation Immediately After Extubation. Vol. 151, Chest. 2017. pp. 166-80.

2. Boles J-M, Bion J, Connors A, Herridge M, Marsh B, Melot C, et al. Weaning from mechanical ventilation. European Respiratory Society; 2007. pp. 1033-56.

3. Zapata L, Vera P, Roglan A, Gich I, Ordonez-Llanos J, Betbesé AJ. B-type natriuretic peptides for prediction and diagnosis of weaning failure from cardiac origin. Intensive Care Med. 2011 Mar;37(3):477-85.

4. Chien J-Y, Lin M-S, Huang Y-CT, Chien Y-F, Yu C-J, Yang P-C. Changes in B-type natriuretic peptide improve weaning outcome predicted by spontaneous breathing trial. Crit Care Med. United States; 2008;36(5):1421-6.

5. Mekontso Dessap A, de Prost N, Girou E, Braconnier F, Lemaire F, Brun-Buisson C, et al. B-type natriuretic peptide and weaning from mechanical ventilation. Intensive Care Med [Internet]. United States; 2006 Aug 29;32(10):1529-36. Available from: http://ovidsp.ovid.com/ovidweb.cgi?T=JS\&PAGE=reference\&D=med5\&NEWS=N\&AN=16941172

6. Zapata L, Vera P, Roglan A, Gich I, Ordonez-Llanos J, Betbesé AJ. B-type natriuretic peptides for prediction and diagnosis of weaning failure from cardiac origin. Intensive Care Med. 2011 Mar;37(3):477-85.

7. Mekontso Dessap A, de Prost N, Girou E, Braconnier F, Lemaire F, Brun-Buisson C, et al. B-type natriuretic peptide and weaning from mechanical ventilation. Intensive Care Med. 2006 Aug 29;32(10):1529-36.

8. Grübler MR, Wigger O, Berger D, Blöchlinger S. Basic concepts of heart-lung interactions during mechanical ventilation. Swiss Med Wkly. 2017 Sep 25;147(3738):w14491.

9. Vieillard-Baron A, Matthay M, Teboul J-L, Bein T, Schultz M, Magder S, et al. Experts' opinion on management of hemodynamics in ARDS patients: focus on the effects of mechanical ventilation. Intensive Care Med. 2016 May;42(5):739-49.

10. Buda AJ, Pinsky MR, Ingels NB, Daughters GT, Stinson EB, Alderman EL. Effect of intrathoracic pressure on left ventricular performance. N Engl J Med. 1979 Aug 30;301(9):453-9.

11. Lemaire F, Teboul J-L, Cinotti L, Giotto G, Abrouk F, Steg G, et al. Acute left ventricular dysfunction during unsuccessful weaning from mechanical ventilation. Anesthesiology. 1988 Aug;69(2):171-9.

12. Capdevila X, Perrigault PF, Ramonatxo M, Roustan JP, Peray $P$, d'Athis F, et al. Changes in breathing pattern and respiratory muscle performance parameters during difficult weaning. Crit Care Med. 1998 Jan;26(1):79-87.

13. Menon N, Joffe AM, Deem S, Yanez ND, Grabinsky A, Dagal AH, et al. Occurrence and complications of tracheal reintubation in critically ill adults. Respir Care. 2012 Oct;57(10):1555-63.

14. Epstein SK, Ciubotaru RL, Wong JB. Effect of failed extubation on the outcome of mechanical ventilation. Chest. 1997 Jul;112(1):186-92.

15. Thille AW, Harrois A, Schortgen F, Brun-Buisson C, Brochard L. Outcomes of extubation failure in medical intensive care unit patients. Crit Care Med. 2011 Dec;39(12):2612-8.

Page 10/19 
16. Moher D, Liberati A, Tetzlaff J, Altman DG, Group TP. Preferred Reporting Items for Systematic Reviews and MetaAnalyses: The PRISMA Statement. PLOS Medicine. Public Library of Science; 2009 Jul 21;6(7):e1000097.

17. Alobaidi R, Morgan C, Basu RK, Stenson E, Featherstone R, Majumdar SR, et al. Associations Between Fluid Balance and Outcomes in Critically III Children: A Protocol for a Systematic Review and Meta-analysis. Can J Kidney Health Dis. 2017;4(8):2054358117692560.

18. McGowan J, Sampson M, Salzwedel DM, Cogo E, Foerster V, Lefebvre C. PRESS Peer Review of Electronic Search Strategies: 2015 Guideline Statement. J Clin Epidemiol. 2016 Jul;75:40-6.

19. Sampson M, McGowan J, Cogo E, Grimshaw J, Moher D, Lefebvre C. An evidence-based practice guideline for the peer review of electronic search strategies. J Clin Epidemiol. 2009 Sep;62(9):944-52.

20. Rewa OG, Villeneuve P-M, Lachance P, Eurich DT, Stelfox HT, Gibney RTN, et al. Quality indicators of continuous renal replacement therapy (CRRT) care in critically ill patients: a systematic review. Intensive Care Med. Springer Berlin Heidelberg; 2017 Jun;43(6):750-63.

21. Lachance P, Villeneuve P-M, Wilson FP, Selby NM, Featherstone R, Rewa O, et al. Impact of e-alert for detection of acute kidney injury on processes of care and outcomes: protocol for a systematic review and meta-analysis. BMJ Open. British Medical Journal Publishing Group; 2016 May 5;6(5):e011152.

22. Whiting PF, Rutjes AWS, Westwood ME, Mallett S, Deeks JJ, Reitsma JB, et al. QUADAS-2: a revised tool for the quality assessment of diagnostic accuracy studies. Annals of Internal Medicine. American College of Physicians; 2011 Oct 18;155(8):529-36.

23. Schünemann HJ, Schünemann AHJ, Oxman AD, Brozek J, Glasziou P, Jaeschke R, et al. Grading quality of evidence and strength of recommendations for diagnostic tests and strategies. BMJ. British Medical Journal Publishing Group; 2008 May 17;336(7653):1106-10.

\section{Tables}




\begin{tabular}{|c|c|c|c|c|c|c|c|c|c|}
\hline Author & $\begin{array}{l}\text { Total } \\
\text { patients }\end{array}$ & Population & $\begin{array}{l}\text { Heart } \\
\text { disease }\end{array}$ & $\begin{array}{l}\text { Renal } \\
\text { failure }\end{array}$ & SBT type & $\begin{array}{l}\text { SBT } \\
\text { failure } \\
\text { status }\end{array}$ & $\begin{array}{l}\text { BNP } \\
\text { type }\end{array}$ & $\begin{array}{l}\text { BNP } \\
\text { measure }\end{array}$ & $\begin{array}{l}\text { Dichotomization } \\
\text { threshold }\end{array}$ \\
\hline $\begin{array}{l}\text { Cheng L } \\
\text { (2015) }\end{array}$ & 56 & $\begin{array}{l}\text { Mixed } \\
\text { population }\end{array}$ & Excluded & Excluded & PS/PEEP & $\begin{array}{l}\text { Exclude } \\
\text { SBT } \\
\text { failure }\end{array}$ & BNP & $\begin{array}{l}\text { DBNP } \\
\text { DBNP\% }\end{array}$ & $\begin{array}{l}80 \mathrm{ng} / \mathrm{L} \\
13.4 \%\end{array}$ \\
\hline $\begin{array}{l}\text { Chien JY } \\
\text { (2008) }\end{array}$ & 52 & $\begin{array}{l}\text { Mixed } \\
\text { population }\end{array}$ & Included & Included & T-tube & $\begin{array}{l}\text { Exclude } \\
\text { SBT } \\
\text { failure }\end{array}$ & BNP & DBNP\% & $20 \%$ \\
\hline $\begin{array}{l}\text { Fang M } \\
\text { (2010) }\end{array}$ & 126 & Septic shock & Included & Unclear & PEEP & $\begin{array}{l}\text { Include } \\
\text { SBT } \\
\text { failure }\end{array}$ & $\begin{array}{l}\text { NT- } \\
\text { proBNP } \\
\text { log NT- } \\
\text { proBNP }\end{array}$ & $\begin{array}{l}\text { Pre-SBT } \\
\text { BNP }\end{array}$ & $3914.5 \mathrm{ng} / \mathrm{L}$ \\
\hline $\begin{array}{l}\text { Fang M } \\
\text { (2013) }\end{array}$ & 52 & Septic shock & Included & Unclear & PEEP & $\begin{array}{l}\text { Include } \\
\text { SBT } \\
\text { failure }\end{array}$ & $\begin{array}{l}\text { NT- } \\
\text { proBNP } \\
\text { log NT- } \\
\text { proBNP }\end{array}$ & $\begin{array}{l}\text { Pre-SBT } \\
\text { BNP }\end{array}$ & $\mathrm{N} / \mathrm{A}$ \\
\hline $\begin{array}{l}\text { Farghaly } \\
\text { S (2015) }\end{array}$ & 30 & $\begin{array}{l}\text { Chronic } \\
\text { respiratory } \\
\text { failure }\end{array}$ & Excluded & Excluded & PS/PEEP & $\begin{array}{l}\text { Include } \\
\text { SBT } \\
\text { failure }\end{array}$ & BNP & $\begin{array}{l}\text { Post- } \\
\text { SBT } \\
\text { BNP } \\
\text { DBNP\% }\end{array}$ & $\begin{array}{l}164 \mathrm{ng} / \mathrm{L} \\
14.9 \%\end{array}$ \\
\hline $\begin{array}{l}\text { Haji K } \\
(2018)\end{array}$ & 53 & $\begin{array}{l}\text { Mixed } \\
\text { population }\end{array}$ & Included & Included & PEEP & $\begin{array}{l}\text { Include } \\
\text { SBT } \\
\text { failure }\end{array}$ & $\mathrm{BNP}$ & $\begin{array}{l}\text { BNP- } \\
\text { post }\end{array}$ & N/A \\
\hline $\begin{array}{l}\text { Hersh D } \\
(2004)\end{array}$ & 23 & $\begin{array}{l}\text { Mixed } \\
\text { population }\end{array}$ & Unclear & Unclear & Unclear & $\begin{array}{l}\text { Exclude } \\
\text { SBT } \\
\text { failure }\end{array}$ & $\mathrm{BNP}$ & $\begin{array}{l}\text { Pre-SBT } \\
\text { BNP }\end{array}$ & N/A \\
\hline $\begin{array}{l}\text { Konomi I } \\
(2016)\end{array}$ & 42 & $\begin{array}{l}\text { Mixed } \\
\text { population }\end{array}$ & $\begin{array}{l}\text { Included } \\
\text { (except } \\
\text { valvulopathy) }\end{array}$ & Included & T-piece & $\begin{array}{l}\text { Include } \\
\text { SBT } \\
\text { failure }\end{array}$ & BNP & $\begin{array}{l}\text { Pre-SBT } \\
\text { BNP }\end{array}$ & $\mathrm{N} / \mathrm{A}$ \\
\hline $\begin{array}{l}\text { Lara TM } \\
\text { (2013) }\end{array}$ & 101 & $\begin{array}{l}\text { Elective } \\
\text { CABG with } \\
\text { CPB }\end{array}$ & Included & $\begin{array}{l}\text { Excluded } \\
\text { (CKD) }\end{array}$ & Unclear & $\begin{array}{l}\text { Include } \\
\text { SBT } \\
\text { failure }\end{array}$ & BNP & $\begin{array}{l}\text { Post- } \\
\text { SBT } \\
\text { BNP }\end{array}$ & $299 \mathrm{ng} / \mathrm{L}$ \\
\hline $\begin{array}{l}\text { Luo L } \\
\text { (2017) }\end{array}$ & 60 & $\begin{array}{l}\text { Mixed } \\
\text { population } \\
\text { (failed } \\
\text { extubation } \\
\text { once) }\end{array}$ & $\begin{array}{l}\text { Included } \\
\text { (except MV } \\
\text { disease) }\end{array}$ & Included & T-tube & $\begin{array}{l}\text { Exclude } \\
\text { SBT } \\
\text { failure }\end{array}$ & $\begin{array}{l}\text { NT- } \\
\text { proBNP }\end{array}$ & $\begin{array}{l}\text { Post- } \\
\text { SBT } \\
\text { BNP }\end{array}$ & $\mathrm{N} / \mathrm{A}$ \\
\hline $\begin{array}{l}\text { Ma G } \\
(2013)\end{array}$ & 29 & $\begin{array}{l}\text { Cancer } \\
\text { patients with } \\
\text { pulmonary } \\
\text { complications } \\
\text { undergoing } \\
\text { noncardiac } \\
\text { major } \\
\text { surgery }\end{array}$ & Excluded & Excluded & T-tube & $\begin{array}{l}\text { Include } \\
\text { SBT } \\
\text { failure }\end{array}$ & $\begin{array}{l}\text { NT- } \\
\text { proBNP }\end{array}$ & $\begin{array}{l}\text { Post- } \\
\text { SBT } \\
\text { BNP }\end{array}$ & $448 \mathrm{ng} / \mathrm{L}$ \\
\hline $\begin{array}{l}\text { Maraghi } \\
\text { SE } \\
(2014)\end{array}$ & 40 & $\begin{array}{l}\text { Mixed } \\
\text { population }\end{array}$ & Excluded & Excluded & T-tube & $\begin{array}{l}\text { Exclude } \\
\text { SBT } \\
\text { failure }\end{array}$ & BNP & DBNP\% & $20 \%$ \\
\hline $\begin{array}{l}\text { Martini A } \\
\text { (2011) }\end{array}$ & 98 & Unclear & Included & Unclear & Unclear & Unclear & $\begin{array}{l}\text { NT- } \\
\text { proBNP }\end{array}$ & DBNP & $\mathrm{N} / \mathrm{A}$ \\
\hline $\begin{array}{l}\text { Mekontso } \\
\text { Dessap A } \\
\text { (2006) }\end{array}$ & 102 & $\begin{array}{l}\text { Mixed } \\
\text { population }\end{array}$ & Included & Excluded & $\begin{array}{l}\text { T-Piece } \\
\text { PS/PEEP }\end{array}$ & $\begin{array}{l}\text { Include } \\
\text { SBT } \\
\text { failure }\end{array}$ & $\mathrm{BNP}$ & $\begin{array}{l}\text { Pre-SBT } \\
\text { BNP } \\
\text { DBNP }\end{array}$ & N/A \\
\hline $\begin{array}{l}\text { Ouanes- } \\
\text { Besbes L } \\
(2012)\end{array}$ & 143 & $\begin{array}{l}\text { Mixed } \\
\text { population }\end{array}$ & Included & $\begin{array}{l}\text { Excluded } \\
\text { (any) }\end{array}$ & T-tube & $\begin{array}{l}\text { Exclude } \\
\text { SBT } \\
\text { failure }\end{array}$ & $\begin{array}{l}\text { NT- } \\
\text { proBNP }\end{array}$ & $\begin{array}{l}\text { Pre-SBT } \\
\text { BNP }\end{array}$ & $\begin{array}{l}\text { Rule-in: } 2000 \\
\text { ng/L } \\
\text { Rule-out: } 1000 \\
\text { ng/L }\end{array}$ \\
\hline $\begin{array}{l}\text { Soummer } \\
\text { A (2012) }\end{array}$ & 100 & $\begin{array}{l}\text { Mixed } \\
\text { population }\end{array}$ & Included & Included & T-tube & $\begin{array}{l}\text { Exclude } \\
\text { SBT }\end{array}$ & BNP & $\begin{array}{l}\text { Post- } \\
\text { SBT }\end{array}$ & $267 \mathrm{ng} / \mathrm{L}$ \\
\hline
\end{tabular}




\begin{tabular}{|c|c|c|c|c|c|c|c|c|c|}
\hline & & & & & & failure & & BNP & \\
\hline $\begin{array}{l}\text { Wang YT } \\
(2016)\end{array}$ & 82 & $\begin{array}{l}\text { Mixed } \\
\text { population }\end{array}$ & Excluded & Excluded & PEEP & $\begin{array}{l}\text { Exclude } \\
\text { SBT } \\
\text { failure }\end{array}$ & $\begin{array}{l}\text { NT- } \\
\text { proBNP }\end{array}$ & $\begin{array}{l}\text { Post- } \\
\text { SBT } \\
\text { BNP }\end{array}$ & N/A \\
\hline $\begin{array}{l}\text { Zapata L } \\
\text { (2011) }\end{array}$ & 100 & $\begin{array}{l}\text { Mixed } \\
\text { population }\end{array}$ & Included & Included & T-tube & $\begin{array}{l}\text { Exclude } \\
\text { SBT } \\
\text { failure }\end{array}$ & $\begin{array}{l}\text { BNP } \\
\text { NT- } \\
\text { proBNP }\end{array}$ & $\begin{array}{l}\text { Pre-SBT } \\
\text { BNP } \\
\text { DBNP }\end{array}$ & $\begin{array}{l}\text { BNP - } 263 \text { ng/L; } \\
\text { NT-ProBNP - } \\
1343 \text { ng/L } \\
\text { DBNP - } 48 \text { ng/L } \\
\text { DNT-ProBNP } \\
\text {-21 ng/L }\end{array}$ \\
\hline
\end{tabular}

Table 1-Included adult studies

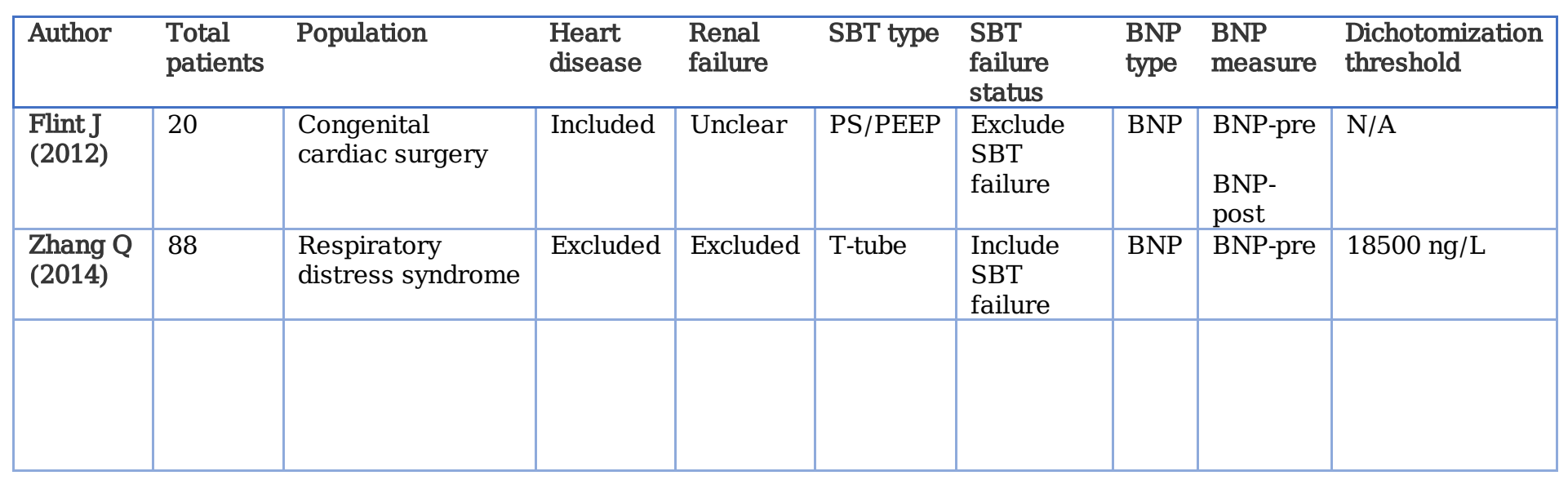

Table 2 - Included pediatric studies

Table 3 - Quality of adult studies 


\begin{tabular}{|c|c|c|c|c|c|c|c|c|c|}
\hline \multicolumn{5}{|c|}{ Risk of Bias } & \multicolumn{5}{|c|}{ Applicability } \\
\hline Authors & $\begin{array}{l}\text { Patient } \\
\text { selection }\end{array}$ & $\begin{array}{l}\text { Index } \\
\text { test }\end{array}$ & $\begin{array}{l}\text { Reference } \\
\text { test }\end{array}$ & Flow/Timing & $\begin{array}{l}\text { Patient } \\
\text { selection }\end{array}$ & $\begin{array}{l}\text { Index } \\
\text { Test }\end{array}$ & $\begin{array}{l}\text { Reference } \\
\text { test }\end{array}$ & $\begin{array}{l}\text { Total } \\
\text { quality }\end{array}$ & Applicability \\
\hline Cheng L (2015) & At risk & $\begin{array}{l}\text { At } \\
\text { risk }\end{array}$ & At risk & Low & No & No & No & At risk & $\begin{array}{l}\text { No } \\
\text { concerns }\end{array}$ \\
\hline Chien JY (2008) & At risk & $\begin{array}{l}\text { At } \\
\text { risk }\end{array}$ & At risk & Low & No & No & No & At risk & $\begin{array}{l}\text { No } \\
\text { concerns }\end{array}$ \\
\hline Chien JY (2008) & At risk & Low & At risk & Low & No & No & No & At risk & $\begin{array}{l}\text { No } \\
\text { concerns }\end{array}$ \\
\hline Fang M (2013) & At risk & $\begin{array}{l}\text { At } \\
\text { risk }\end{array}$ & At risk & Low & No & No & No & At risk & $\begin{array}{l}\text { No } \\
\text { concerns }\end{array}$ \\
\hline Fang M (2010) & At risk & $\begin{array}{l}\text { At } \\
\text { risk }\end{array}$ & At risk & Low & No & No & No & At risk & $\begin{array}{l}\text { No } \\
\text { concerns }\end{array}$ \\
\hline $\begin{array}{l}\text { Farghaly S } \\
\text { (2015) }\end{array}$ & At risk & $\begin{array}{l}\text { At } \\
\text { risk }\end{array}$ & At risk & Low & No & No & No & At risk & $\begin{array}{l}\text { No } \\
\text { concerns }\end{array}$ \\
\hline Haji K (2018) & At risk & $\begin{array}{l}\text { At } \\
\text { risk }\end{array}$ & At risk & Low & No & No & No & At risk & $\begin{array}{l}\text { No } \\
\text { concerns }\end{array}$ \\
\hline Hersh D (2004) & At risk & $\begin{array}{l}\text { At } \\
\text { risk }\end{array}$ & At risk & At risk & No & No & No & At risk & $\begin{array}{l}\text { No } \\
\text { concerns }\end{array}$ \\
\hline Konomi I (2016) & Low & $\begin{array}{l}\text { At } \\
\text { risk }\end{array}$ & Low & Low & No & No & No & At risk & $\begin{array}{l}\text { No } \\
\text { concerns }\end{array}$ \\
\hline Lara TM (2013) & Low & $\begin{array}{l}\text { At } \\
\text { risk }\end{array}$ & At risk & Low & No & No & No & At risk & $\begin{array}{l}\text { No } \\
\text { concerns }\end{array}$ \\
\hline Luo L (2017) & At risk & $\begin{array}{l}\text { At } \\
\text { risk }\end{array}$ & At risk & Low & No & No & No & At risk & $\begin{array}{l}\text { No } \\
\text { concerns }\end{array}$ \\
\hline Ma G (2013) & Low & Low & Low & Low & No & No & No & At risk & $\begin{array}{l}\text { No } \\
\text { concerns }\end{array}$ \\
\hline $\begin{array}{l}\text { Maraghi SE } \\
\text { (2014) }\end{array}$ & Low & $\begin{array}{l}\text { At } \\
\text { risk }\end{array}$ & At risk & Low & No & No & No & At risk & $\begin{array}{l}\text { No } \\
\text { concerns }\end{array}$ \\
\hline $\begin{array}{l}\text { Martini A } \\
\text { (2011) }\end{array}$ & At risk & $\begin{array}{l}\text { At } \\
\text { risk }\end{array}$ & At risk & At risk & No & No & No & At risk & $\begin{array}{l}\text { No } \\
\text { concerns }\end{array}$ \\
\hline $\begin{array}{l}\text { Mekontso } \\
\text { Dessap A } \\
\text { (2006) }\end{array}$ & Low & $\begin{array}{l}\text { At } \\
\text { risk }\end{array}$ & Low & Low & No & No & No & At risk & $\begin{array}{l}\text { No } \\
\text { concerns }\end{array}$ \\
\hline $\begin{array}{l}\text { Ouanes-Besbes } \\
\text { L (2012) }\end{array}$ & Low & $\begin{array}{l}\text { At } \\
\text { risk }\end{array}$ & At risk & Low & No & No & No & At risk & $\begin{array}{l}\text { No } \\
\text { concerns }\end{array}$ \\
\hline $\begin{array}{l}\text { Soummer A } \\
\text { (2012) }\end{array}$ & Low & Low & Low & Low & No & No & No & Low & $\begin{array}{l}\text { No } \\
\text { concerns }\end{array}$ \\
\hline Wang YT (2016) & Low & $\begin{array}{l}\text { At } \\
\text { risk }\end{array}$ & At risk & At risk & No & No & No & At risk & $\begin{array}{l}\text { No } \\
\text { concerns }\end{array}$ \\
\hline Zapata L (2011) & At risk & $\begin{array}{l}\text { At } \\
\text { risk }\end{array}$ & Low & Low & No & No & No & At risk & $\begin{array}{l}\text { No } \\
\text { concerns }\end{array}$ \\
\hline Flint J (2012) & At risk & $\begin{array}{l}\text { At } \\
\text { risk }\end{array}$ & Low & At risk & No & No & No & At risk & $\begin{array}{l}\text { No } \\
\text { concerns }\end{array}$ \\
\hline Zhang Q (2014) & At risk & $\begin{array}{l}\text { At } \\
\text { risk }\end{array}$ & Low & At risk & No & No & No & At risk & $\begin{array}{l}\text { No } \\
\text { concerns }\end{array}$ \\
\hline
\end{tabular}

Table 4- Quality of pediatric studies

\begin{tabular}{|c|c|c|c|c|c|c|c|c|c|}
\hline \multicolumn{5}{|c|}{ Risk of bias } & \multicolumn{5}{|c|}{ Applicability } \\
\hline Authors & $\begin{array}{l}\text { Patient } \\
\text { selection }\end{array}$ & $\begin{array}{l}\text { Index } \\
\text { test }\end{array}$ & $\begin{array}{l}\text { Reference } \\
\text { test }\end{array}$ & Flow/Timing & $\begin{array}{l}\text { Patient } \\
\text { selection }\end{array}$ & $\begin{array}{l}\text { Index } \\
\text { Test }\end{array}$ & $\begin{array}{l}\text { Reference } \\
\text { test }\end{array}$ & $\begin{array}{l}\text { Total } \\
\text { quality }\end{array}$ & Applicability \\
\hline $\begin{array}{l}\text { Flint J } \\
(2012)\end{array}$ & At risk & Low & Low & Low & Low & Low & Low & At risk & $\begin{array}{l}\text { No } \\
\text { concerns }\end{array}$ \\
\hline $\begin{array}{l}\text { Zhang Q } \\
\text { (2014) }\end{array}$ & At risk & At risk & At risk & Low & Low & Low & Low & At risk & $\begin{array}{l}\text { No } \\
\text { concerns }\end{array}$ \\
\hline
\end{tabular}


Figure 1-Flow diagram for study assessment

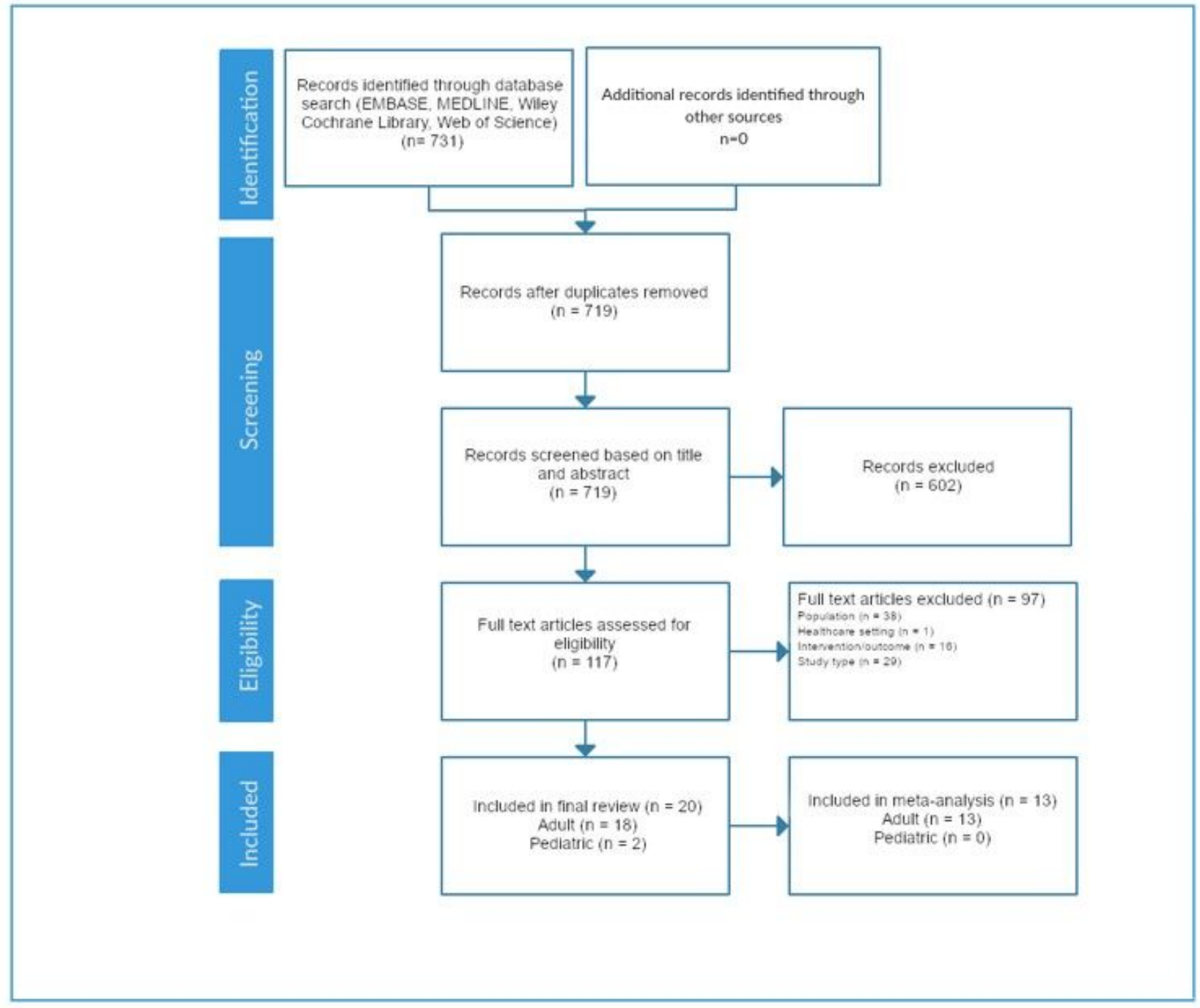

Figure 1

Flow diagram for study assessment 


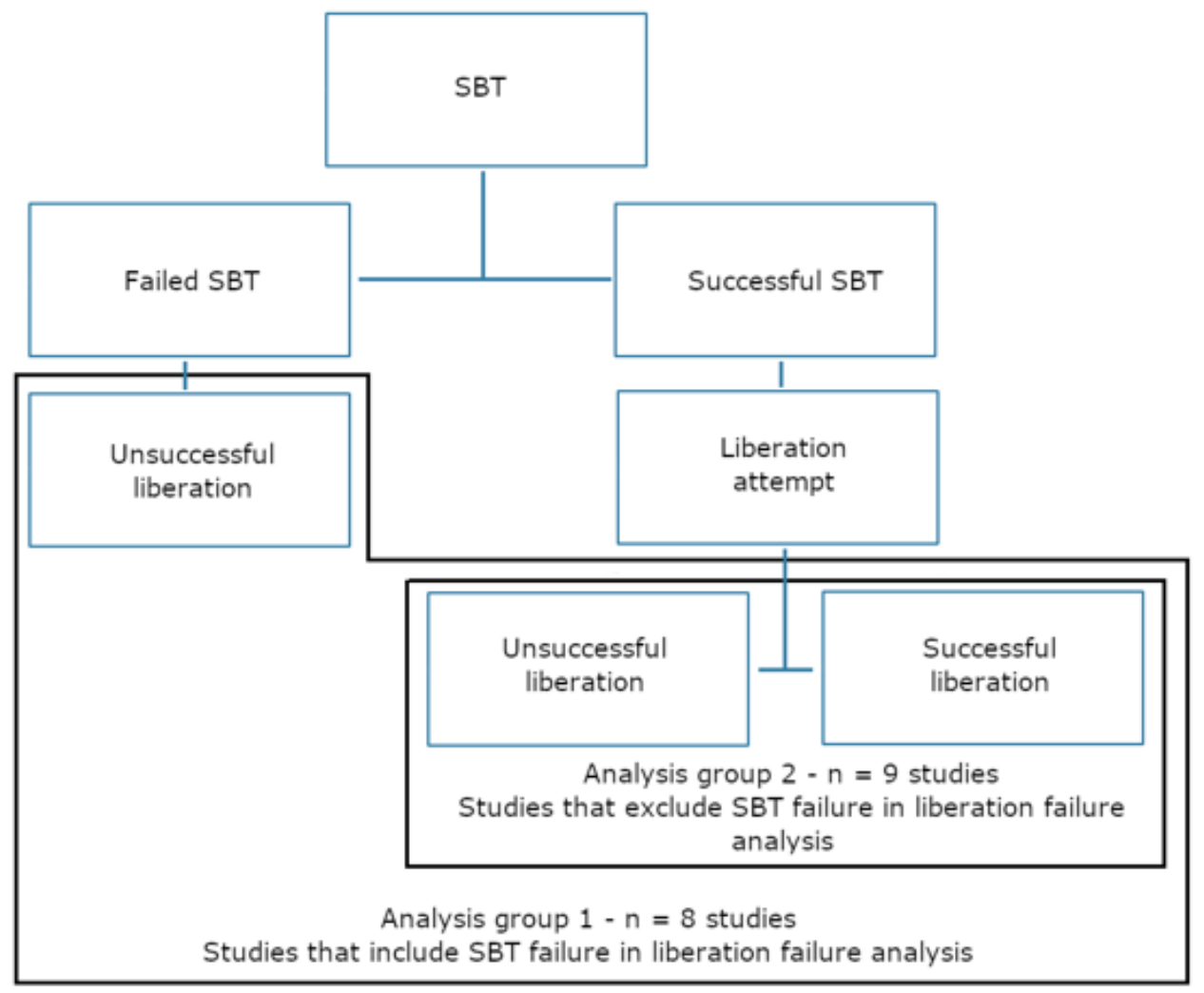

Unclear if included or excluded SBT from liberation failure analysis - $n=1$ study (Martini 2011)

SBT: Spontaneous breathing trial; successful liberation: absence of non-invasive ventilation or reintubation at 48 ; unsuccessful liberation: failure of SBT or non-invasive ventilation or reintubation at $48 \mathrm{~h}$.

This flow diagram details how the different stages at which unsuccessful liberation from mechanical ventilation were handled in regard to statistical analysis. Group 1 included SBT failure within the unsuccessful liberation umbrella for analysis of liberation failure. Group 2 excluded SBT failure from the umbrella of unsuccessful liberation for the purpose of analvses of liberatio failure.

\section{Figure 2}

Flow diagram of group allocation for inclusion versus exclusion of SBT failure in the liberation failure analysis. 

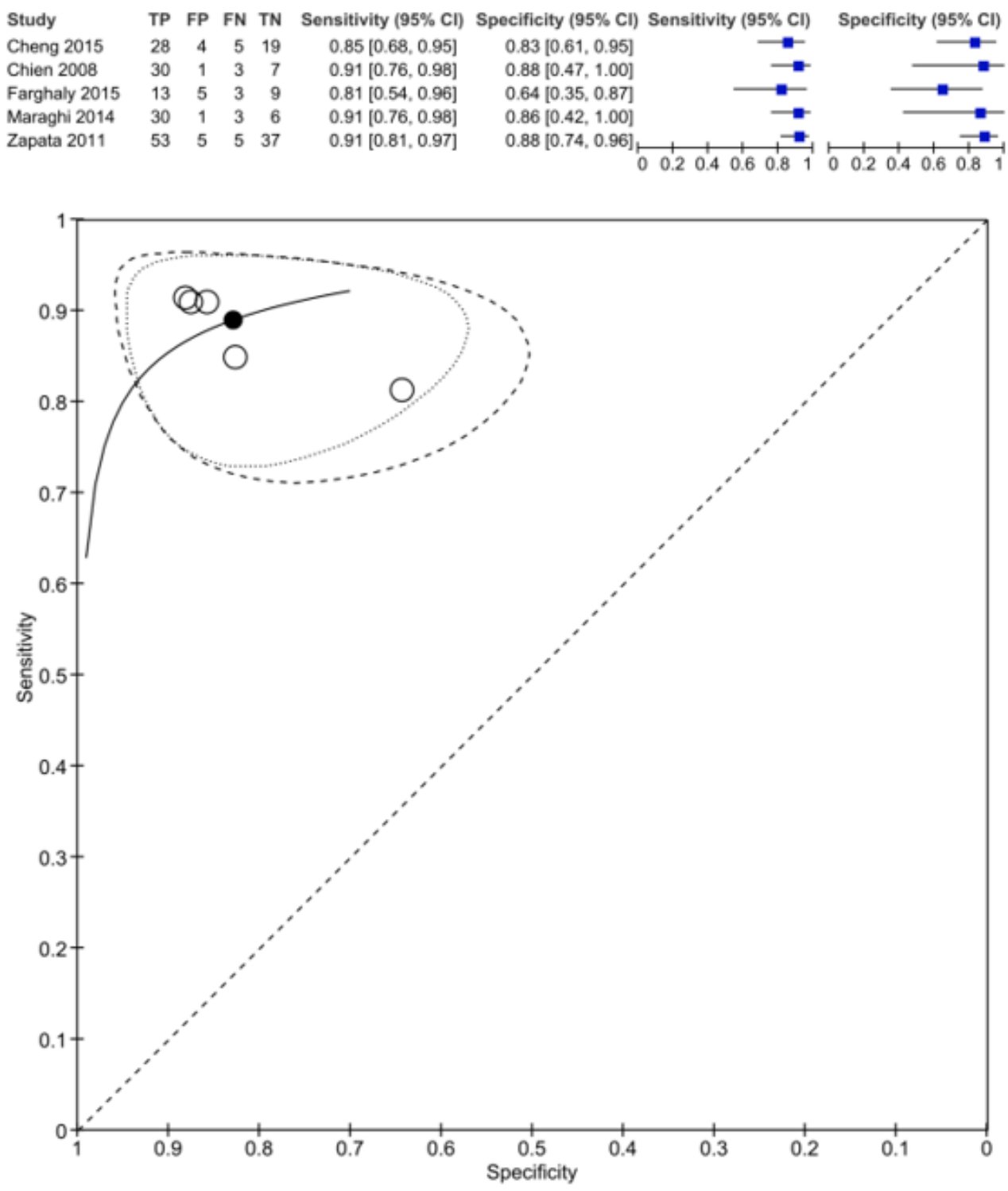

Bi-variate estimate of sensitivity and specificity: Sensitivity - $0.889(0.831,0.929)$; Specificity $-0.828(0.730,0.896)$

TP: True positive; TN: True negative; FP: False positive; FN: False negative.

\section{Figure 3}

Bi-variate estimate of sensitivity and specificity for measures of either $\Delta B N P$ or $\Delta B N P \%$ in studies that included SBT failure (group 1) and studies that excluded SBT failure (group 2) from liberation failure analysis. 
AUC

AUC

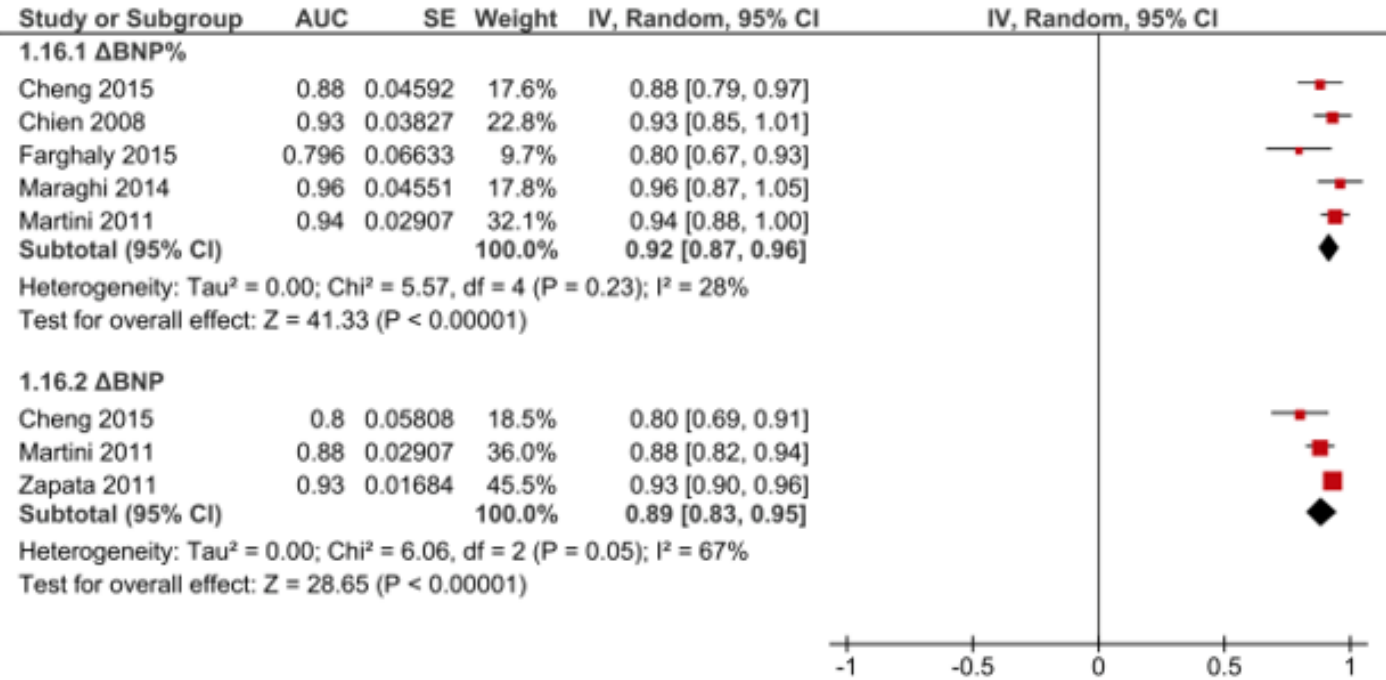

Test for subqroup differences: $\mathrm{Chi}^{2}=0.57, \mathrm{df}=1(\mathrm{P}=0.45), \mathrm{I}^{2}=0 \%$

These figures illustrate the individual AUC obtained from the studies for each method of BNP measurement separately ( $\triangle B N P$ and $\triangle B N P \%$ ). Both studies that included SBT failure (group 1) and excluded SBT failure (group 2) in liberation failure analysis were included to increase statistical power. The pooled AUC for $\triangle B N P \%$ showed a high AUC with low heterogeneity, while the pooled AUC for $\triangle B N P$ showed a high AUC with moderate heterogeneity.

\section{Figure 4}

Pooled diagnostic AUC for either $\triangle B N P$ or $\triangle B N P \%$ methods of measurements, in studies that included SBT failure (group 1) and studies that excluded SBT failure (group 2) from liberation failure analysis.

AUC

AUC

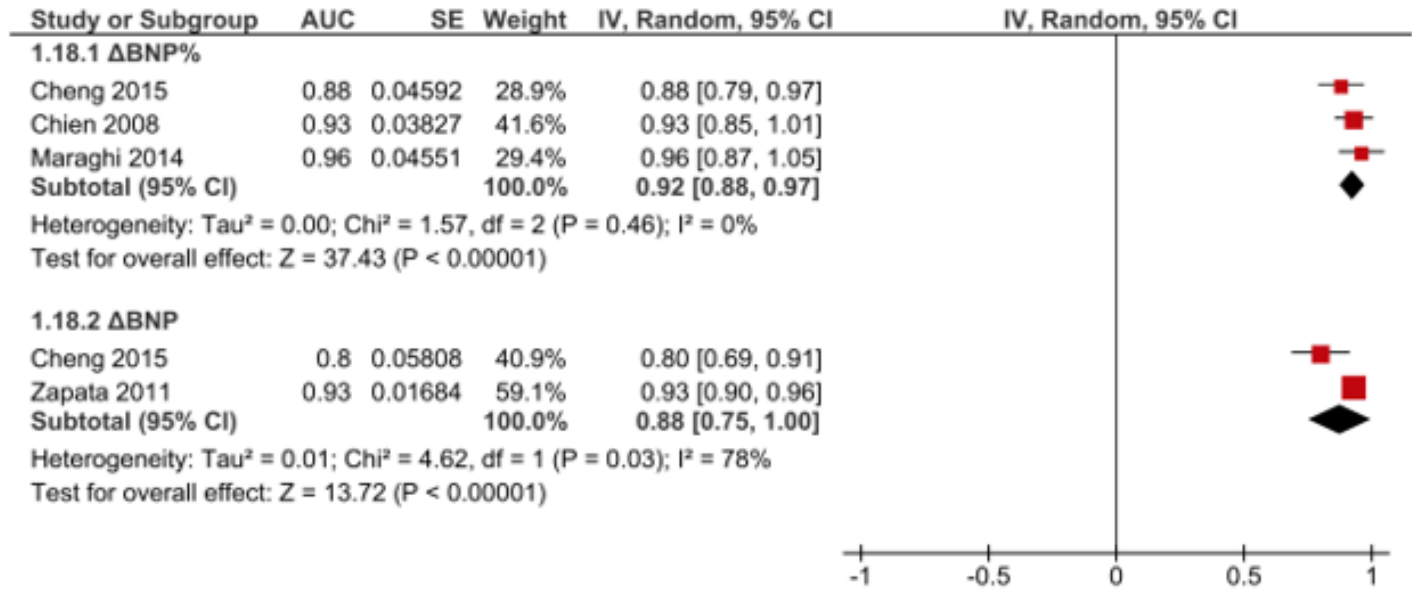

Test for subaroup differences: $\mathrm{Ch}^{2}=0.48, \mathrm{df}=1(\mathrm{P}=0.49), \mathrm{I}^{2}=0 \%$

These figures illustrate the individual AUC obtained from the studies for each method of $\triangle B N P$ and $\triangle B N P \%$ measurements separately. Only studies that excluded SBT failure (group 2) in liberation failure analysis were included to provide more precise data of a specific clinical subgroup. The pooled AUC for $\triangle B N P \%$ showed a high AUC with low heterogeneity. The pooled AUC for $\triangle B N P$ showed a high AUC and high heterogeneity but is limited by the inclusion of only 2 studies in the analysis.

\section{Figure 5}


Pooled diagnostic AUC either $\triangle B N P$ or $\triangle B N P \%$ methods of measurements in studies that excluded SBT failure (group 2) from liberation failure analysis.

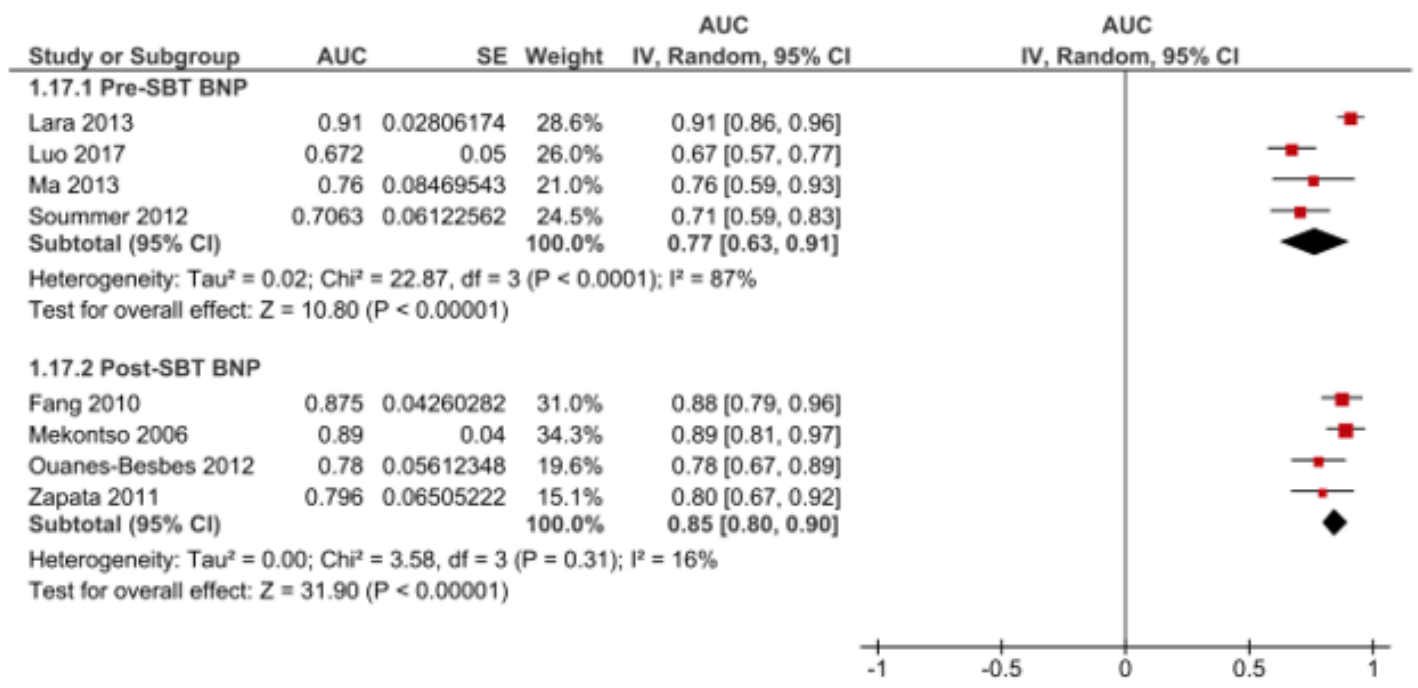

Test for subaroup differences: $\mathrm{Chi}^{2}=1,19, \mathrm{df}=1(\mathrm{P}=0.27), \mathrm{I}^{2}=16.2 \%$

These figures illustrate the individual AUC obtained from the studies for each method of individual measures of $B N P$ separately (BNP-pre and BNP-post). Both studies that included SBT failure (group 1) and excluded SBT failure (group 2) in liberation failure analysis were included to increase statistical power. The pooled AUC for $B N P$-pre showed a moderate-high AUC with high heterogeneity. The pooled AUC for BNP-post showed a high AUC and low heterogeneity.

\section{Figure 6}

Pooled diagnostic AUC of either BNP-Pre or BNP-post methods of measurement in studies that included SBT failure (group 1) and studies that excluded SBT failure (group 2) from liberation failure analysis.

\section{Supplementary Files}

This is a list of supplementary files associated with this preprint. Click to download.

- Additionalfile3.docx

- AdditionalFile6ForestPlothighquality.pdf

- AdditionalFile5.docx

- AdditionalFile6.docx

- AdditionalFile5forestplothighquality.pdf

- AdditionalFile6SROCplothighquality.pdf

- Additionalfile4.docx

- AditionalFile5SROCplothighquality.pdf

- Additionalfile2.docx

- Additionalfile1.docx 